\title{
Condition of teeth vs. eating habits and other health behaviours of young adults
}

\author{
Stan uzębienia a nawyki żywieniowe i inne zachowania zdrowotne \\ młodych dorosłych
}

\author{
Monika Bujnowska ${ }^{1, A-D \oplus}$, Agnieszka Strzelecka ${ }^{1, B-C \oplus}$, Kamil Markowski $^{1, B-C} \oplus$, Edyta Dziewisz ${ }^{1, B-D \oplus}$, \\ Anna Beata Pacian ${ }^{2, A, E \oplus}$, Teresa Kulik ${ }^{2, E \oplus}$, Monika Kaczoruk ${ }^{2,3, B}{ }^{\oplus}$, Anna Jachowicz ${ }^{4, B}{ }^{\oplus}$, \\ Grażyna Nowak-Starz $1, A, F \oplus$ \\ ${ }^{1}$ Collegium Medicum, Jan Kochanowski University, Kielce, Poland \\ ${ }^{2}$ Chair of Public Health, Medical University, Lublin, Poland \\ ${ }^{3}$ Doctoral Studies, Institute of Rural Health, Lublin, Poland \\ ${ }^{4}$ Student, Medical University, Łódź, Poland \\ A - Research concept and design, B - Collection and/or assembly of data, C - Data analysis and interpretation, \\ $D$ - Writing the article, E - Critical revision of the article, F - Final approval of article
}

Bujnowska M, Strzelecka A, Markowski K, Dziewisz E, Pacian AB, Kulik T, Kaczoruk M, Jachowicz A, Nowak-Starz G. Condition of teeth vs. eating habits and other health behaviours of young adults. Med Og Nauk Zdr. 2020; 26(3): 268-274. doi: 10.26444/monz/124632

\section{Abstract}

Introduction. Oral health is an integral part of the overall health of the body. Dental caries and periodontal diseases are conditions determined mostly by environmental factors and health behaviours. In order to cope with them it is often necessary to change eating habits and modify unhealthy behaviours.

Objective.The aim of the study is to evaluate the condition of the teeth and periodontium of young adults in the context of their lifestyle as a result of healthy and unhealthy behaviours. Materials and method. The study covered a group of 250 students aged 19-22, in general good healthy, who were patients of the Centermed Clinic in Kielce. A diagnostic survey with a questionnaire was used as well as evaluation of a dental examination of the study participants.

Results. The results of analyses revealed that the examined students displayed numerous unhealthy behaviours connected with their diet, such as: skipping breakfast, having fizzy drinks, eating fast food, snacking between meals, and eating insufficient vegetables and fruit. There were correlations between negative health behaviours connected with diet and objective dental indices.

Conclusions. 1)The oral health of the examined young people, expressed with the indices studied (DMF, PD, SiC, BoP), requires definite improvement and dental intervention. 2) Young adults display numerous unhealthy behaviours despite being aware of the adverse influence on their general condition and oral health. 3)There was a correlation between the oral health of the examined young people and healthy and unhealthy behaviours.

\section{Key words}

health behaviours, lifestyle, conservative dentistry

\section{Streszczenie}

Cel pracy. Stan zdrowia jamy ustnej jest integralną częścią stanu zdrowia całego organizmu. Próchnica i choroby przyzębia są chorobami modyfikowanymi głównie przez czynniki środowiskowe i zachowania zdrowotne i do ich opanowania niejednokrotnie konieczna jest zmiana nawyków żywieniowych i modyfikacja zachowań antyzdrowotnych. Celem podjętych badań była ocena stanu uzębienia i przyzębia młodych dorosłych w kontekście ich stylu życia jako wyniku sumarycznego zachowań pro- i antyzdrowotnych.

Materiał i metody. Badaniami objęto grupę ok. 250 studentów w wieku 19-22 lat, ogólnie zdrowych, pacjentów przychodni Centermed w Kielcach. Podstawową metodą zastosowaną w pracy był sondaż diagnostyczny z zastosowaniem techniki ankietowania oraz ocena badania stomatologicznego badanych.

Wyniki. Wyniki przeprowadzonych analiz wykazały, że badani studenci prezentują liczne zachowania antyzdrowotne związane z dietą, takie jak: unikanie spożywania śniadań, picie napojów gazowanych, spożywanie posiłków typu fast food i podjadanie między posiłkami, jednocześnie ograniczając spożycie warzyw i owoców. Istnieją korelacje pomiędzy negatywnymi zachowaniami zdrowotnymi związanymi z dietą a obiektywnymi wskaźnikami stomatologicznymi.

Wnioski. 1. Stan zdrowia jamy ustnej badanej młodzieży wyrażony badanymi wskaźnikami (PUW, PD, SiC, BoP) wymaga zdecydowanej poprawy i interwencji stomatologicznej. 2. Młodzi dorośli prezentują liczne zachowania antyzdrowotne mimo świadomości ich negatywnego wpływu na ogólny stan zdrowia i stan zdrowia jamy ustnej. 3. Istnieje związek między stanem zdrowia jamy ustnej badanej młodzieży a zachowaniami pro- i antyzdrowotnymi.

\section{Słowa kluczowe}

zachowania zdrowotne, styl życia, stomatologia społeczna, stomatologia zachowawcza

\footnotetext{
Address for correspondence: Anna Beata Pacian, Chair of Public Health, Medical University, Lublin, Poland E-mail: apacian@gmail.com

Received: 25.03.2020; accepted: 25.06.2020; first published: 17.07.2020
} 


\section{INTRODUCTION}

Oral health is an integral part of general health. Oral diseases are important components of noncommunicable diseases (NCDs), which continue to be a leading public health problem in the WHO European Region where tooth decay among 6 -year-old children varies from $20 \%-90 \%$, depending on the country [1]. In the age group of $65-74$-year-olds, the prevalence of those who have lost all their natural teeth ranges from about 20-o 50\%. People without natural teeth may have functional problems, which detracts from their quality of life [2]. According to the WHO, dental caries and periodontal disease, similar to other lifestyle diseases such as excess weight, affect the whole of society, and their treatment and consequences of absence from work due to them are a considerable burden, both to the home budget and the State budget $[3,4,5]$.

In accordance with research by the WHO, dental caries is one of the major problems of highly developed and developing countries [5], with dental caries among 6-year-old children accounting for $20 \%-90 \%[1,5]$. The number of elderly people suffering from loss of teeth is $20 \%-50 \%$, which results in considerably lower quality of life in these people $[3,4,5]$.

In recent years, there have been numerous studies on the influence of the condition of teeth and periodontium on advancements in the treatment of general diseases, especially coronary artery disease and diabetes [6]. The WHO decided to include dental prevention into chronic disease prevention programmesas an element of major importance for the general health and quality of life of patients $[7,8]$.

A consequence of the habits acquired during adolescence is the condition of teeth and the practices of young adults who are just beginning their independent life, and will be developing their views on health care and their own healthy routines, and passing this knowledge to and shaping the next generation, including health habits of their own children. The participants of the study were at the age suitable for starting their own families [9].

At the time of numerous programmes promoting broadly understood healthy lifestyle (practising sports, eating sufficient fresh vegetables and fruit, compensating for electrolyte deficits with isotonic drinks), the new problem of tooth erosion has emerged among people who take great care of their health and hygiene. Moreover, people from this group tend to use hard toothbrushes and brush their teeth just after a meal at the time of enamel demineralization, using the most abrasive brushing method - scrubbing. This can lead to irreversible changes on tooth surface and cavities not related to dental caries $[10,11]$. This proves the necessity of education about oral hygiene in all groups of children and young people, even those who lead a healthy lifestyle.

\section{OBJECTIVE}

The aim of the study was to evaluate the condition of teeth and periodontium of young adults in the context of their eating habits.

\section{MATERIALS AND METHOD}

After obtaining the consent of the Bioethics Committee (No. $25 / 20176.10 .2017$ ), the study was carried out in $2018-2019$ and covered a group of 253 students (139 women and 114 men), in general good health, who were patients of Centermed Clinic in Kielce. The participants were students at the Jan Kochanowski University and Kielce University of Technology who did not report systemic diseases in their medical history, and who gave their consent to the research. The study was conducted in a representative sample of students aged 19-22.

The basic method used in the study was a diagnostic survey with a questionnaire technique, as well as an intraoral dental examination of the participants. The dental examination evaluated:

1) DMF (decayed-missing-filled) index;

2) dental caries treatment index;

3) 3) conservative treatment needs;

4) 4) BoP (bleeding on probing) index;

5) 5) OHI (oral hygiene index);

6) 6) PD (pocket depth).

A diagnostic survey with a questionnaire constructed by the authors was used,. The questionnaire contained 30 detailed questions about the lifestyle affecting the general state of health (diet, approach to exercise, care for rest, way of rest, presence of addictions), and questions about the care of teeth and dental care (knowledge of principles of oral hygiene, approach to dental treatment, frequency of office visits, current preventive measures). The questionnaire was created so that the approach to the topic of health reflected the way in which the participants approached the topic of oral health.

In the process of statistical analysis, the following methods of classical statistics were used:

1) Statistical description methods: the following were calculated for each variable:

- arithmetic mean;

- standard deviation.

2) Methods for evaluating significance of differences between compared groups:

- Chi-square test to evaluate correlations between dependent and independent variables (level of significance was adopted at $\mathrm{p}$ 0.05);

- Mann-Whitney U test.

3) Correlation analysis method:

- Pearson correlation coefficient (Pearson's r) to evaluate correlation strength between variables (level of significance was adopted p 0.05);

- Cramér's V.

4) All calculations were performed with STATISTICA 10 software.

\section{RESULTS}

Analysis of the correlation between dental indices and health behaviours connected with diet and other health behaviours: DMF index is a measurable (quantitative) variable and takes discrete values: $0,1,2, \ldots, 20$. With such a 'fragmentation' of values it is very difficult to notice correlations, even at a positive performance of a test. Therefore, the variability range of DMF index is divided into four categories: very low, low, high and very high (Fig. 1). 


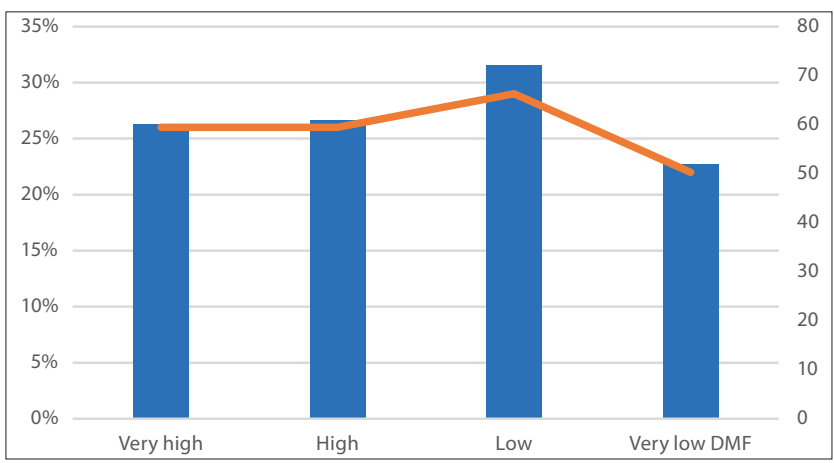

Figure 1. Distribution of people with respect to DMF index

Analysis of the correlation between tooth brushing frequency declared and DMF index revealed that less frequent tooth brushing resulted in higher DMF - 14 (61\%) respondents who brushed their teeth once a day had a very high DMF. Similarly, the higher the OHI level, the higher the DMF index - 31 (60\%) respondents with OHI 3 had very high DMF.

Many respondents who had a high and very high DMF index wrongly evaluated the condition of their teeth as good or average - 48 (49\%) respondents with very high DMF index and $52(52 \%)$ respondents with high DMF index. There was a weak correlation between DMF index and evaluation of the condition of one's own teeth by the respondents. The lower the evaluation, the higher the DMF index.

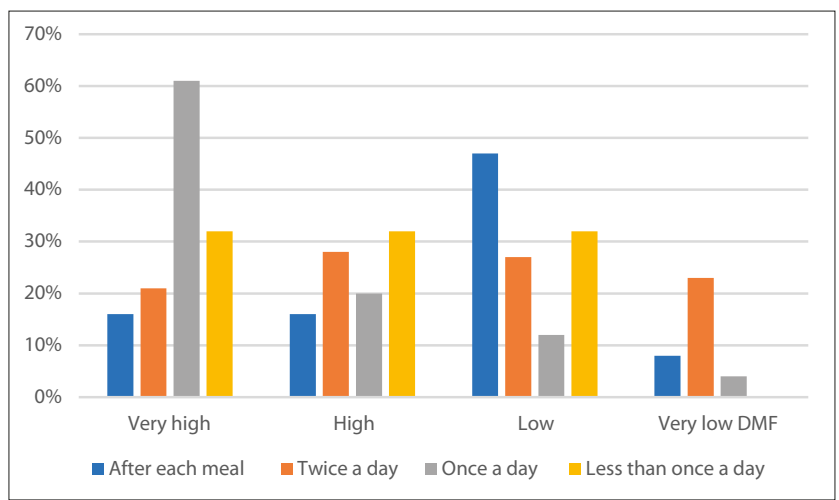

Figure 2. Correlation between DMF and tooth brushing frequency

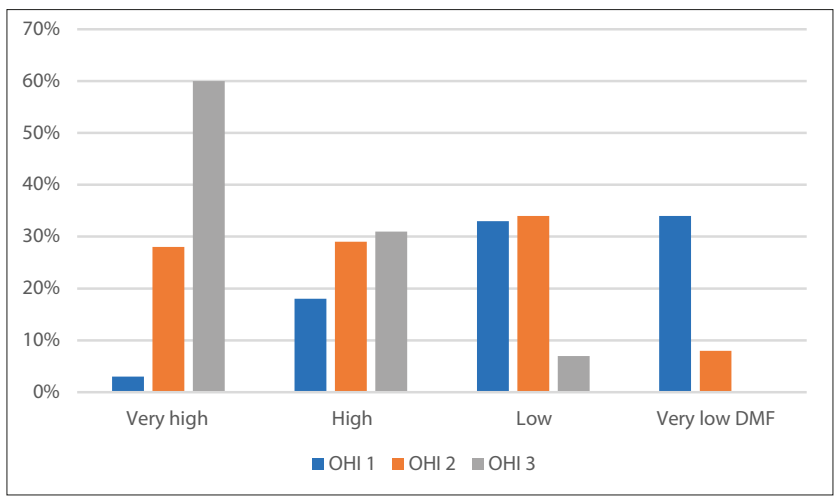

Figure 3. Correlation between DMF and $\mathrm{OHI}$

The Mann-Whitney U test was performed for the DMF variable with all the variables which had two levels of values (e.g. gender). Similarly as in other tests, conclusions were drawn on the basis of p-value. If it was lower than the significance level $\alpha=0.05$ the hypothesis was rejected

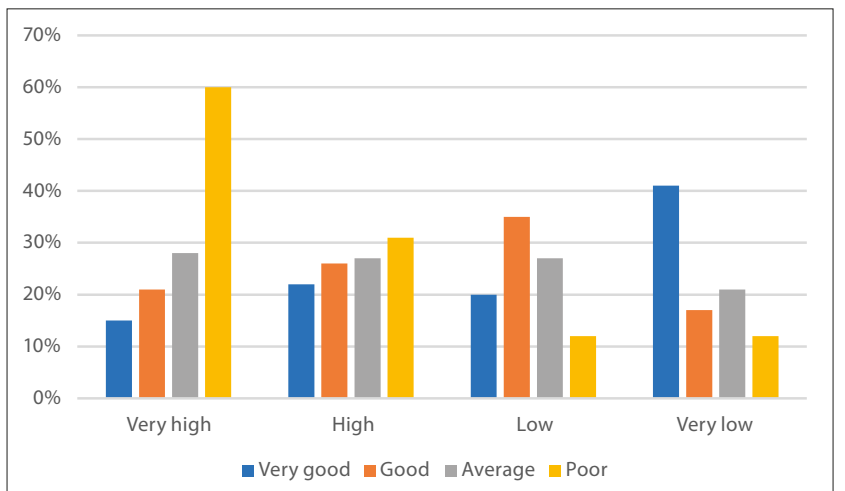

Figure 4. Correlation between DMF and subjective evaluation of condition of own teeth

about the equality of the median values, and were regarded as different. In only four cases the median values were different in the subgroups of the examined students. A higher median value of DMF variable was observed in the group of respondents who did not mention poor diet as an unhealthy behaviour. The median value of the DMF variable was lower in the group of participants whose parents took care of a diet rich in fruit and vegetables.

Table 1. Attitude to poor diet as an unhealthy behaviour vs. DMF value

\begin{tabular}{lcccccc}
\hline U Mann-Whitney test, $p<0.05$ & & & & & \\
\hline $\begin{array}{l}\text { Poor diet as an unhealthy } \\
\text { behaviour }\end{array}$ & $\begin{array}{c}\text { DMF } \\
\text { mean value }\end{array}$ & $\begin{array}{c}\text { Rank } \\
\text { sum }\end{array}$ & $U$ & $Z$ & $p$ \\
\hline Yes & 9 & 4792 & 3711.00 & 2.2965 & 0.021 \\
\hline No & 10 & 27086 & & & \\
\hline
\end{tabular}

Table 2. Eating vegetables and fruit in childhood vs. DMF value

\begin{tabular}{lcccccc}
\hline U Mann-Whitney test, $\mathrm{p}<0.05$ & & & & & \\
\hline $\begin{array}{l}\text { Eating much vegetables } \\
\text { and fruit in childhood }\end{array}$ & $\begin{array}{c}\text { DMF } \\
\text { mean value }\end{array}$ & $\begin{array}{c}\text { Rank } \\
\text { sum }\end{array}$ & $\mathrm{U}$ & $\mathrm{Z}$ & $\mathrm{p}$ \\
\hline Yes & 9 & 15779.5 & 6599.5 & -2.24542 & 0.024 \\
\hline
\end{tabular}

The treatment index is a measurable (quantitative) variable and takes values within the range of $[0,1]$. Since there are many different values of this variable, its variability range is divided into four categories: very low, low, high and very high. Quartiles are used for this purpose, with the following values: $\mathrm{Q}_{1}=0.4167, \mathrm{Q}_{2}=$ Median value $=0.66667, \mathrm{Q}_{3}=0.875$.

Distribution of the analysed variable is different for the female and male respondents. About $50 \%$ of men (46 respondents) had a high or very high treatment index, while about $40 \%$ of women ( 42 respondents) had such index values. Cramér's $\mathrm{V}$ at the level of 0.19 indicated a weak correlation between the variables.

Analysis of the research results demonstrated that people who snacked on sweet buns -12 (50\%) respondents, or sweets and salty snacks - 47 (51\%) respondents, had a high or very high treatment index rather more frequently, similar to the group of respondents who declared using dental floss 41 (58\%) respondents]. The correlations were weak.

In the group of students participating in the research, a high or very high treatment index occurred the most frequently at $\mathrm{OHI}=2-48(51 \%)$ respondents, and the least frequently at $\mathrm{OHI}=3-13(25 \%)$ respondents. The correlation was quite noticeable $(\mathrm{V}=0.29)$. 


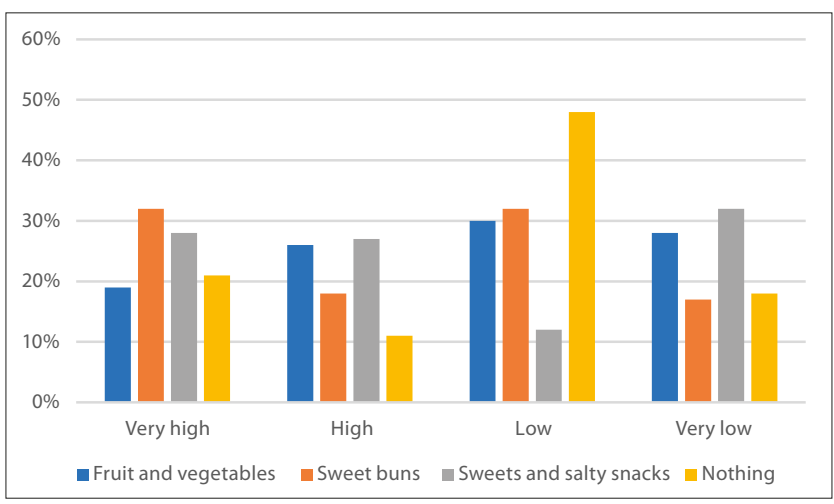

Figure 5. Treatment index vs. snacks between meals

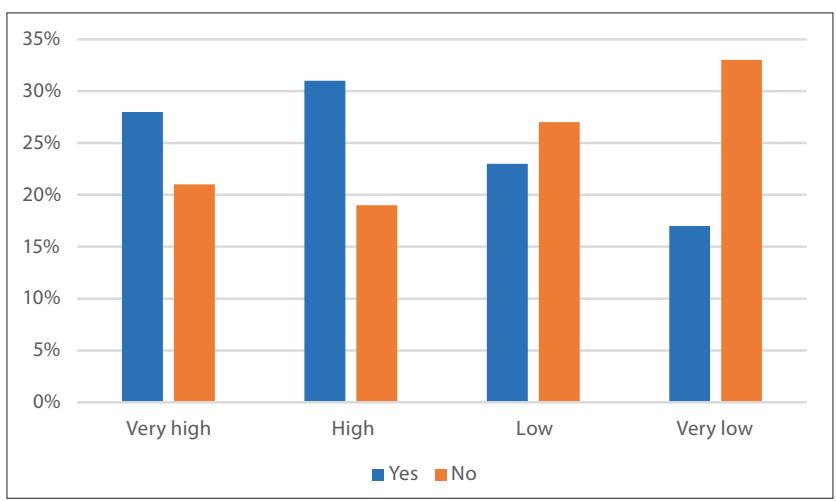

Figure 6. Treatment index depending on dental floss use

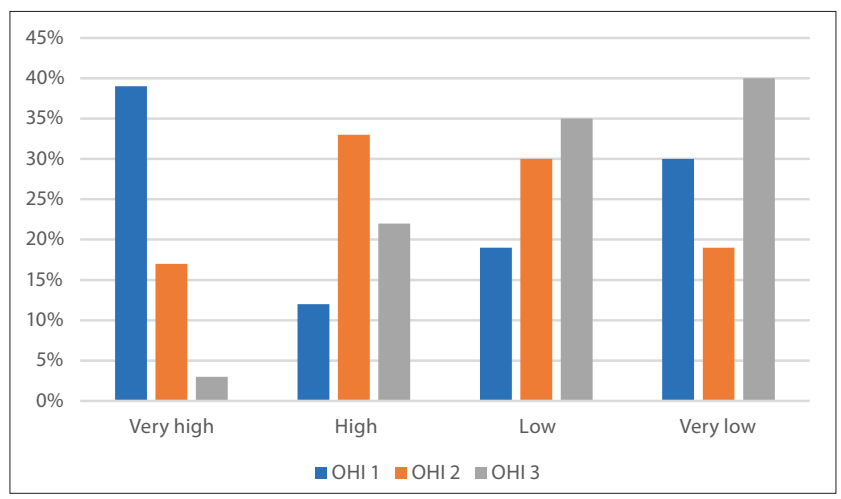

Figure 7. Treatment index vs. oral hygiene expressed in $\mathrm{OHI}$

OHI is a quantitative variable already classified into four categories at the stage of questionnaire assessment. Consequently, it was assumed that it is a variable expressed solely in the ordinal scale. Moreover, the first category 'No plaque or calculus on tooth surface' was adopted for only one person. Due to so scarce representation among the respondents, this category was omitted in further statistical analysis.

The research results obtained show that the male respondents presented better oral hygiene than the female respondents. There was a lower share of women than men with OHI 1 - 69 (50\%) men and 36 (31\%) women, and higher with OHI 2 - 30 (21\%) men and 55 (48\%) women. The correlations for these two OHI levels are quite noticeable, even though, taking into account all OHI values, Cramér's $\mathrm{V}$ indicates weak interdependence.

Analysis of OHI values depending on the opinions concerning dental check-ups in a dentist's surgery as one of the measures to prevent oral cavity diseases, demonstrated that among those who claimed that it is necessary to have one's teeth checked to keep them healthy, there were more respondents with OHI $1-47$ (44\%) respondents, and fewer with OHI 3 - 13 (12\%) respondents. The correlation was weak.

A similar correlation was observed with respect to frequency of brushing the teeth. Among the respondents who brushed their teeth more frequently, there was a higher proportion of those with OHI $1-23$ (70\%) respondents, which means that they had less plaque or calculus on their teeth. On the other hand, among the respondents who brushed their teeth less often, there was a higher proportion of those with OHI 3, which means that there was more plaque or calculus on their teeth $-8(35 \%)$ respondents brushed their teeth once a day. The respondents who did not brush their teeth every day were omitted from the interpretation, because there were so few of them (3). This correlation was stronger than in previous cases.

There was also a positive correlation between evaluation of the condition of one's own teeth and OHI: the better the evaluation of the condition own teeth, the higher the share with OHI $1-18$ (46\%) respondents who evaluated the condition of their teeth as very good, and $50(48 \%)$ respondents who evaluated the condition of their teeth as good].

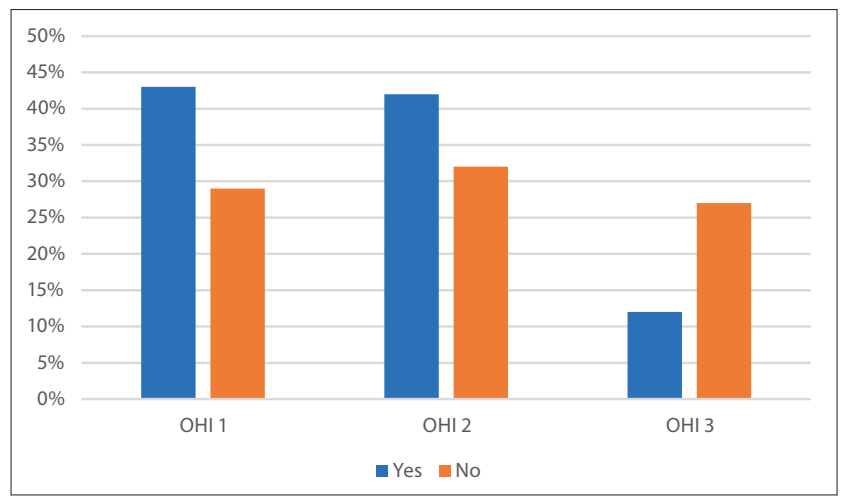

Figure 8. $\mathrm{OHI}$ and opinions concerning dental check-ups as a factor preventing dental caries

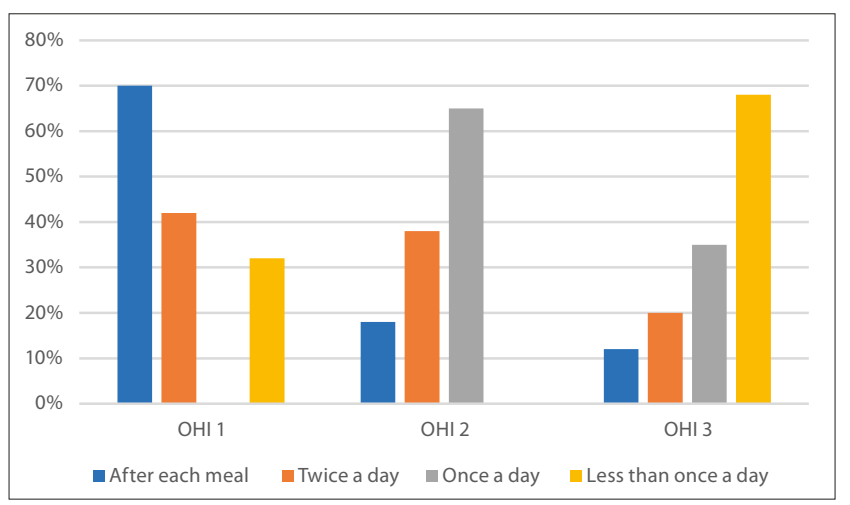

Figure 9. OHI vs. frequency of brushing teeth

$\mathrm{BoP}$ is a dichotomous variable indicating whether there is bleeding on probing (value 1) or not (value 0 ). It can be noticed that $78 \%$ of the respondents do not experience bleeding.

The analysis of the research results shows that among people who evaluate the condition of their teeth [11 (79\%) respondents] and oral hygiene [17 (63\%) respondents] as unsatisfactory, there is a considerably higher share of people with bleeding in comparison to other respondents. The correlation is noticeable. 


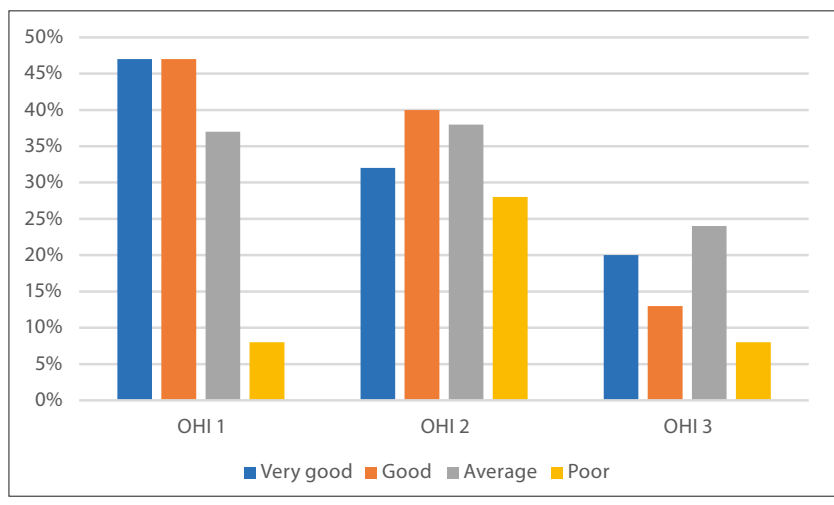

Figure 10. OHI vs. subjective evaluation of the condition of teeth

The results of the analyses demonstrate that there is a positive correlation between $\mathrm{OHI}$ and BoP index. The respondents with higher $\mathrm{OHI}$ are characterized by more frequent incidence of bleeding [39 (75\%) respondents with OHI 3].

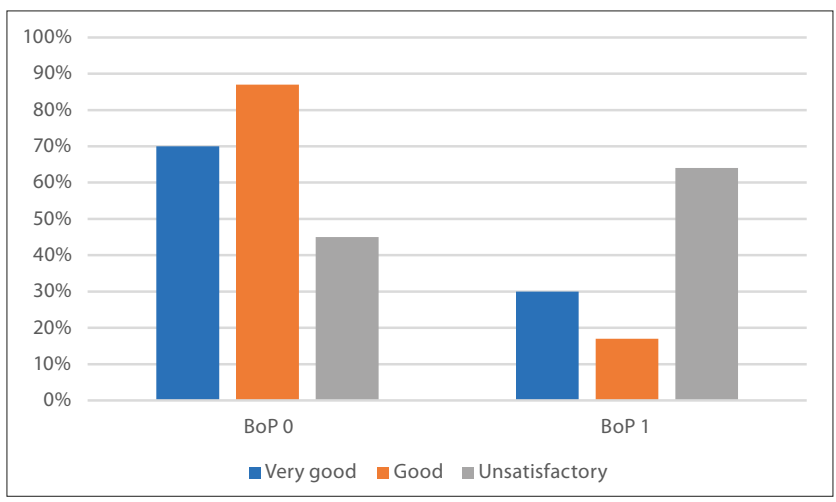

Figure 11. BoP index vs. subjective evaluation of oral hygiene

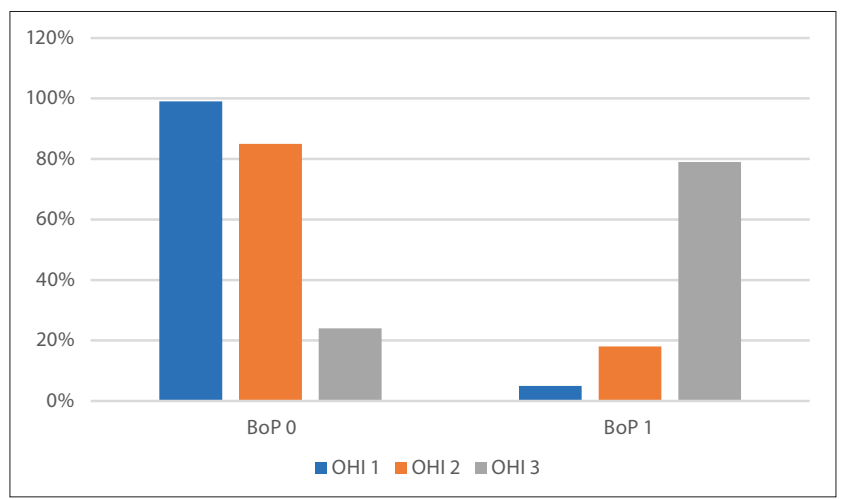

Figure 12. BoP index vs. OHI

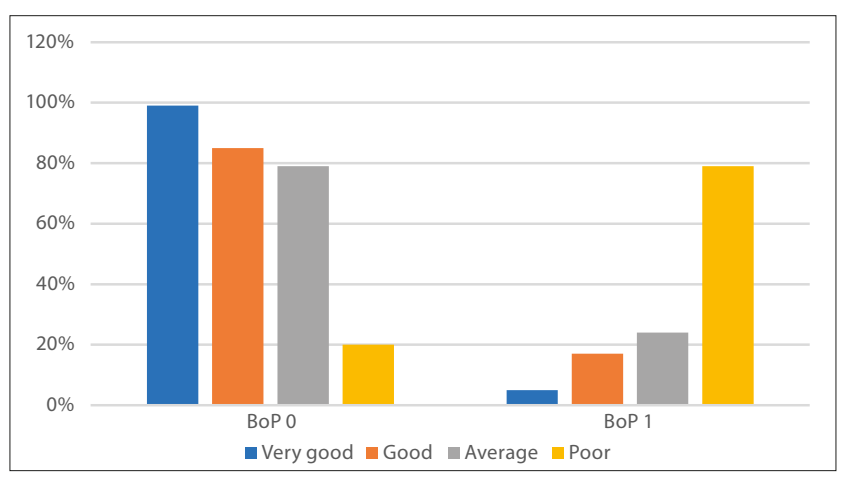

Figure 13. BoP index vs. subjective evaluation of teeth condition
The incidence and intensity of periodontium diseases with or without alveolar bone loss can be evaluated with the pocket depth index (PD). Physiologically, pocket depth should not exceed 2, while higher values suggest periodontal inflammation. Analysis of the PD index shows that the predominant depth of the periodontal pockets is 2, this proved to be the case in 214 (85\%) respondents, with value 3 noted in 30 (ca. 12\%) respondents. Other values were represented by marginal numbers.

Results of the analyses indicate that among people who claimed that it is necessary to have one's teeth checked to keep them healthy, a proportion of those with a higher pocket depth was over three times smaller - 5 (5\%) respondents and $24(17 \%)$ respondents, repectively.

Oral hygiene has a considerable influence on the health of the periodontium, expressed in periodontal pocket depth (PD); it is therefore not surprising that the higher the respondents' OHI, the bigger their share of deeper pockets - 20 (42) respondents with $\mathrm{OHI} 3$. The correlation was very noticeable.

Analysis of the correlation between pocket depth and subjective evaluation of the condition of one's own teeth, demonstrated that among the those who assessed their dental health as unsatisfactory, there was a higher proportion of respondents with deeper pockets, compared to those who evaluated their dental health as good or very good - 19 (63\%) respondents.

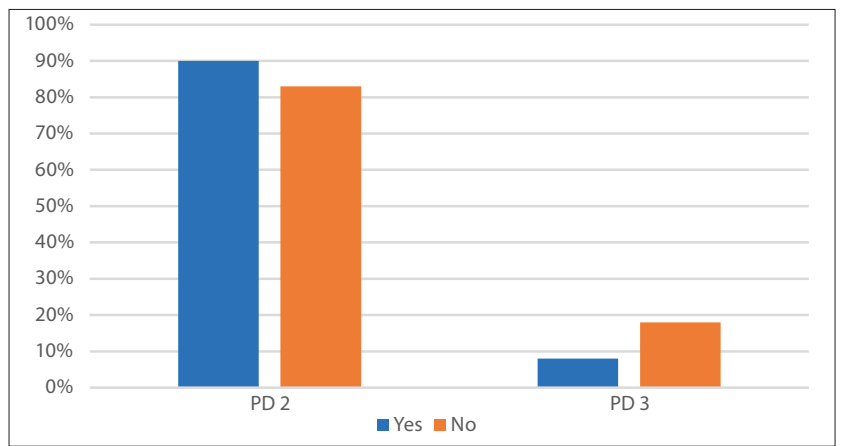

Figure 14. PD index vs. attitude to check-up visits in a dental surgery

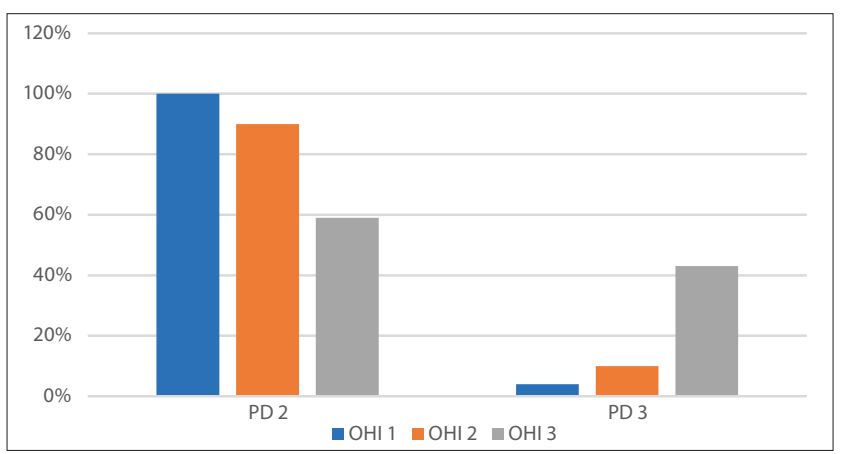

Figure 15. PD index vs. OHI

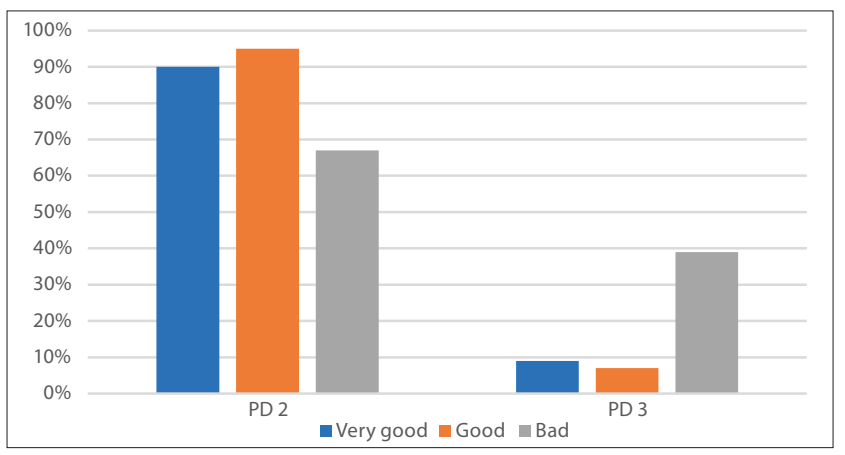

Figure 16. PD index vs. subjective evaluation of condition of one's own teeth 


\section{DISCUSSION}

Numerous studies conducted worldwide have demonstrated a high incidence and intensity of dental caries among young people [12]. A positive aspect is the modern trend of improved health behaviours and prevention of neoplastic diseases, diabetes, cardiac illnesses, and other lifestyle diseases, but in many countries prevention of dental caries and periodontal disease is not a part of this trend $[1,3,4]$. The reason for this, as indicated by the analysis carried out by D. E. Piotrowska et al., may be the income level, source of income, and education level among rural and urban populations, as well as differences between these populations. This could imply that health disparities arise not only from economic constraints and unavailability of health care, but also from health attitudes and behaviours [13].

The current study also reveals a state of oral hygiene with at a high incidence and intensity of dental caries, and other health behaviours. Results of the analyses show the incidence of dental caries at the level of $97 \%, 28 \%$ of the respondents had a DMF index at the level of $8.5-11.42$; research analysis results also indicated the lower quartile at the DMF level of 6 and the upper quartile at the level of 12.5. The respondents with worse oral hygiene manifested in frequency of brushing the teeth - once a day in $14(61 \%)$ respondents, and OHI value -3 in $31(60 \%)$ respondents, had a very high DMF index (above 12.5).

In similar research carried out among students in Lublin, the DMF index was 11.94, and among students in Białystok - 14.24 [13]. In Łódź, the incidence of dental caries was $70 \%$, and average DMF index was 5.25 among those young people examined who displayed correct health behaviours. In another group of respondents, the incidence of dental caries was $80.4 \%$, average DMF index - 7.17 [14].

A comparison between the research results obtained in the current study and the results obtained by other researchers shows that inflammation manifested by gum bleeding occurred less frequently in the group examined by the authors of this study. Analysis of the study results showed bleeding on probing in the case of $22 \%$ of the respondents. Bleeding was more frequent in respondents with high $\mathrm{OHI}-$ bleeding occurred in 39 (75\%) respondents with OHI 3]. The distribution of $\mathrm{OHI}$ established in the current study indicated that the respondents' oral hygiene was not very good. Only one person had a complete absence of plaque/calculus, while about $58 \%$ of the students had plaque/calculus on at least $2 / 3$ of the surface of the teeth. The male respondents - 69 (50\%) participants, had OHI 1 more often than female respondents - 36 (31\%) participants.

Among respondents in Kraków, 68.3\% reported periodic gum inflammation manifested in gum bleeding, and $43.6 \%$ of the respondents had never had calculus removed [15].

In connection with the current results of actions aimed at improvement of knowledge about health behaviours and oral hygiene, and the unsatisfactory oral health of the respondents, it is necessary to undertake regular educational and preventive actions concerning lifestyle, including oral hygiene, in all age groups: children, young people and adults. There is abundant evidence demonstrating that the success of oral health promotion interventions delivered in the dental office depends on the character, values, personality, and people skills of the dental surgeon. Data show that if such professionals do not believe that oral hygiene instructions will improve the health of their patient, then that professional will be less likely to practice an effective oral health promotion strategy $[16,17]$. It is apparent that teaching health psychology to dentists would make oral health promotion more effective in dentistry [17]. As indicated by the WHO, the Ministry of Health should ensure that the mechanisms for intersectorial collaboration are carefully considered. Strategies include taxation and pricing, food labelling, school lunch policies and support of nutrition programmes [18].

\section{CONCLUSIONS}

1. The oral health of the examined young people, expressed with the indices studied (DMF, $\mathrm{PD}, \mathrm{SiC}, \mathrm{BoP})$, requires definite improvement and dental intervention.

2. Young adults display numerous unhealthy behaviours related to diet, despite being aware of their adverse influence on general and oral health.

3. There is a correlation between the oral health of the examined young people and healthy and unhealthy behaviours.

\section{REFERENCES}

1. World Health Organisation. Diet and oral health Report 2018. World Health OrganizationRegional Office for Europe, 2018.

2. Petersen PE, Ogawa H. Prevention of dental caries through the use of fluoride-the WHO approach. Community Dent Health. 2016;33(2):66-68.

3. Kwan S, Petersen PE. Oral health: equity and social determinants. In: Blas E, Sivansankara Kurup A, eds. Equity, social determinants and public health programmes. World Health Organization, Geneva; 2010. p. 159-176.

4. Rasińska R, Nowakowska I, Nowomiejski J. Diagnoza stanu zdrowia studentów i ich opinie o zagrożeniach zdrowotnych. Piel Pol. 2013; 2: 79-84.

5. Petersen PE, Kandelman D, Arpin S, Ogawa H. Global oral health of older people - call for public health action. Community Dent Health. 2010; $27: 1-11$.

6. GBD 2015 Disease and Injury Incidence and Prevalence Collaborators. Global, regional, and national incidence, prevalence, and years lived with disability for 310 diseases and injuries, 1990-2015: a systematic analysis for the Global Burden of Disease Study 2015. Lancet. 2016;8:1545-1602. doi: 10.1016/S0140-6736(16)31678-6

7. Petersen PE. Global policy for improvement of oral health - World Health Assembly 2007. Int Dental J. 2008. doi:10.1922/IDJ_1930Petersen07

8. World Health Organisation. Guideline: sugars intake for adults and children. WHO, 2015

9. Reddy V, Bennadi D, Gaduputi S, Kshetrimayum N, Siluvai S, Konda Reddy VCh. Oral health related knowledge, attitude, and practice among the pre-university students of Mysore city. J Int Soc Prev Community Dent. 2014; 4(3): 154-158. doi: 10.4103/2231-0762.142012

10.Strużycka I, Rusyan E, Bogusławska-Kapała A. Występowanie Erozji szkliwa w populacji młodych dorosłych w wieku 18 lat w Polsce. Przegl Epidemiol. 2014; 68: 775 - 778.

11. Gruszczyńska M, Bąk-Sosnowska M, Plinta R. Zachowania zdrowotne jako istotny element aktywności życiowej człowieka. Stosunek Polaków do własnego zdrowia. Hygeia Public Health 2015; 50: 558-565.

12. GBD 2016 Disease and Injury Incidence and Prevalence Collaborators. Global, regional, and national incidence, prevalence, and years lived with disability for 328 diseases and injuries for 195 countries, 1990-2016: a systematic analysis for the Global Burden of Disease Study 2016. Lancet. 2017; 390(10100):1211-1259.

13. Piotrowska DE, Pędziński B, Jankowska D, Dorota Huzarska D, Angelika Edyta Charkiewicz AE, Szpak AS. Socio-economic inequalities in the use of dental care in urban and rural areas in Poland. Ann Agric Environ Med. 2018;25(3):512-516.

14. DOI: https://doi.org/10.26444/aaem/...

15. Królewska-Gawarzyńska J. Stomatologiczne zachowania prozdrowotne, a stan uzębienia łódzkiej młodzieży 18-letniej. Nowa Stomatol. 2015; 4: 153-158. 
16. Majda A, Zalewska-Puchała J. Bodys-Cupak I, Czubak-Lewandowska E. Stan higieny jamy ustnej i stomatologiczne zachowania zdrowotne studentów kierunków medycznych. Probl Hig Epidemiol. 2014; 95: 895-900.

17. Amoo-Achampong F, Vitunac DE, Deeley K, Modesto A, Vieira AR. Complex patterns of response to oral hygiene instructions: longitudinal evaluation of periodontal patients. BMC Oral Health. 2018; 18(72). DOI: https://doi.org/10.1186/s12903...
18. Kay E, Vascott D, Hocking A, Nield H, Dorr C, Barrett H. A review of approaches for dental practice teams for promoting oral health. Community Dent Oral Epidemiol. 2016; 44:313-30. DOI: doi: 10.1111/ cdoe. 12220

19. World Health Organization. Oral health surveys: basic methods -5 th ed. WHO Library Cataloguing-in-Publication Data 2013. 